\title{
Christian faith for ordinary Christians
}

\section{Book Title:}

Kijk op Geloof Christelijk geloof uitgelegd

\section{Book Cover:}

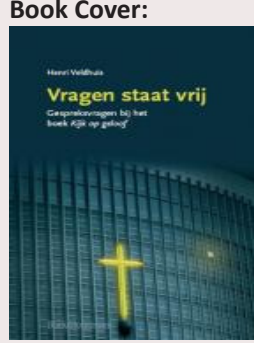

Author:

Henri Veldhuis

ISBN:

9789023918134

Publisher:

Boekencentrum,

Zoetermeer, 2005, p. 287,

$€ 16.50 *$

*Book price at time of Review

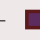

Review Title:

Christian faith for ordinary

Christians

Reviewer:

André J. Groenewald ${ }^{1}$

\section{Affiliation:}

${ }^{1}$ Department of Dogmatics and Christian Ethics,

University of Pretoria,

South Africa

Email:

groenstes@yahoo.com

Postal address:

Department of Dogmatics

and Christian Ethics, Faculty

of Theology, University of

Pretoria, Pretoria 0002,

South Africa

How to cite this book

review:

Groenewald, A.J., 2011,

'Christian faith for ordinary

Christians', HTS Teologiese

Studies/Theological Studies

67(3), Art. \#1126, 1 page.

doi:10.4102/hts.v67i3.1126

(C) 2011. The Authors.

Licensee: AOSIS

OpenJournals. This work

is licensed under the

Creative Commons

Attribution License.
'Kijk op Geloof Christelijk geloof uitgelegd', is an explanation of the Christian faith for ordinary Christians. The author says in his introduction that his intention is to explain the Christian faith according to the Bible and the tradition in which this faith was expressed. He wants to provide the reader with a vision of faith in which the Bible and tradition play an important role.

He explains in 52 chapters all the key issues of the Christian faith, such as God, Faith, Revelation, the Bible, the Trinity, Creation, Man, Freedom, Creation and suffering. The chapters are short with not one over six pages long. The author succeeds in his mission to provide the ordinary believer with the basics of the Christian faith. He frequently refers to the Bible in all the chapters, which will definitely prove be a good resource for the reader to discover more truths.

Although the book is well written in layman terms, it is a pity that the author did not refer to other primary and secondary literature on the abovementioned topics. It creates the impression that the author covered all the topics, whilst ignoring any new insights gained from research in the field of theology. In my opinion, the author should have conveyed more results of research done in the field of Biblical studies. To me it prevents him from presenting the fuller biblical picture to the reader. Chapter 46 (pp. 244-248) is an example. In this chapter the author does not mention that 'homosexuality' is an anachronism of the biblical practice of 'pediastry'. This and other insights will most definitely help the reader to understand the existence of a historical consciousness when reading the Bible.

I can recommend this book for its logical, systematic consistency and easy-articulated formulations. 